Covered in: ERIH PLUS, HeinOnline, CEEOL, Index Copernicus, CrossRef, CrossCheck, J-GATE, Google Scholar, Ideas RePeC, Econpapers, Socionet, KVK, WorldCat.

2019, Volume 7, Issue 1, pages: 49-60 | doi: 10.18662/lumenlaw/18

\section{Unfair Competition Actions in the Online Field}

\section{[Acţiunile de concurență neloială în domeniul on-line]}

\section{Cornelia GORINCIOI ${ }^{1}$, Iulian MORARU ${ }^{2}$, Violeta COJOCARU ${ }^{3}$}

${ }^{1} \mathrm{PhD}$ in law, Moldova State University, Chișinău, Republic of Moldova, kornelia 78@yahoo.com

${ }^{2} \mathrm{PhD}$ in law candidate, Moldova State University, Chişinău, Republic of Moldova, iulian.moraru94@gmail.com

${ }^{3} \mathrm{PhD}$ hab. in law., Moldova State University, Chişinău, Republic of Moldova, violetacojocaru@yahoo.fr
Abstract: The article approaches world trends of reorientation of TV and outdoor advertising towards Internet. However, in the process of on-line space occupation, unfair competitors continue to commit unfair competition acts, which are often manifested by inadequate advertising. At the same time, in the article there are elucidated the particularities of unfair competition acts identified in the on-line space, being presented as well the case law of the competition authority from Republic of Moldova. The article contains as well the argumentation of the necessity of the on-line advertising regulation, analyzing the existing law and presenting the data of the World Intellectual Property Organization, which denote a numeric growth of cases of infringement of trademarks right holders in the on-line domain.

Keywords: Advertising; unfair competition; on-line space; trademark; case.

How to cite: Gorincioi, C., Moraru, I., \& Cojocaru, V. (2019). Unfair Competition Actions in the Online Field. Logos Universality Mentality Education Novelty: Law, 7(1), 49-60. doi:10.18662/lumenlaw/18 


\section{Introducere}

În fiecare an Internetul devine din ce în ce mai solicitat pentru promovarea bunurilor şi serviciilor. Mii de companii încearcă să atragă atenția publicului on-line multimilionar.

Astfel, în Europa de Vest internetul se bucură de o cota medie de $34,9 \%$ din piaţa publicității, având o creştere enormă în ultimii 5 ani (de la $21 \%$ în 2011). Cea mai mare cotă deținută de piaţa digitală se înregistrează în Marea Britanie - 52,7\%, urmată de Danemarca, 50,8\%.

T,ările din Europa Centrală şi de Est au o cotă mai mică, cea mai mare fiind în Rusia (37,8\%), Polonia (33,3\%) şi Ungaria (32,1\%).

În România, cota deținută de piața digitală este similară celei din Moldova, reprezentând 15\% din piața publicității, în timp ce Ucraina a atins deja $27 \%$.

În România, în ultimii ani, Internetul a crescut cu aproximativ 20\% pe an. În țările dezvoltate, creşterea anuală a veniturilor din internet este mult mai mică (12\% în Europa de Vest, $9 \%$ în America de Nord), piaţa publicității digitale fiind deja matură şi având o cotă considerabilă în piaţa publicitatea.

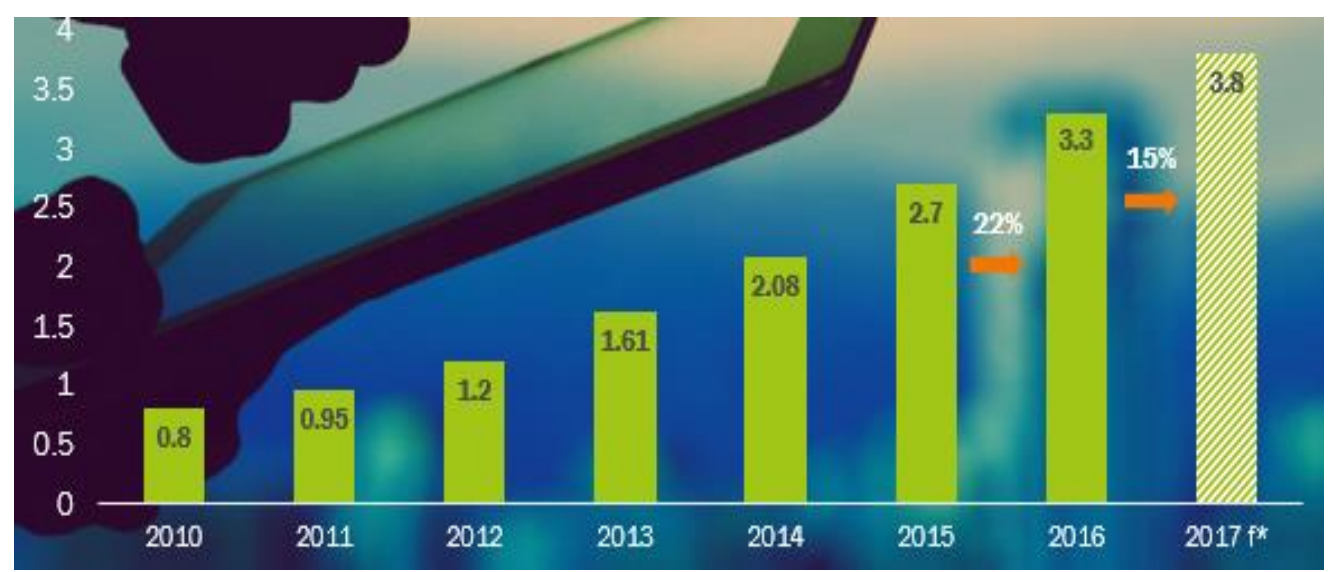

Nivelul cheltuielilor pe publicitatea online 2010 - 2017 (mln. Euro), conform datelor Asociației Agențiilor Publicitare din Moldova

În Republica Moldova, aşa cum s-a întâmplat şi în multe alte țări în curs de dezvoltare, creşterea bugetelor este motivată prin creşterea acoperirii internetului şi este şi un rezultat al migrării audienței de la TV spre internet.

Segmentul pieței digitale, care a înregistrat cele mai mari creşteri în ultimii ani, este reprezentat de rețelele sociale, care au crescut în $\bmod$ 
continuu de la 38\% utilizatori de internet în 2013, până la 48\% în 2017. Publicitatea prin intermediul rețelelor sociale oferă oportunitatea de a ajunge la consumatorul publicității, prin aplicarea unor criterii legate de regiune, sex, vârstă şi preferințe, fapt care reprezintă un mare avantaj comparativ cu celelalte tipuri de publicitate.

Agenții mari de publicitate transferă bugetele de la TV către mediul digital, acest mediu fiind la fel de profitabil ca şi publicitatea TV, pentru anumite segmente (în cea mai mare parte pentru tineret) şi mai profitabil, iar costul per contact este mai mic.

In Republica Moldova, cea mai mare cotă a bugetelor de publicitate pe Internet aparţine furnizorului internațional Google - 33\% din piaţă.

Însă, cu tot succesul de care se bucură piaţa publicității on-line, acest sector este reglementat insuficient. Iar participanții pieții, folosindu-se de lacunele legislative şi dorind să-şi mărească vânzările, încep să parcurgă la acțiuni mau puțin oneste. În mediul on-line concurenții neloiali cel mai des întreprind aşa acțiuni ca: folosirea ilegală a mărcilor străine în propria lor publicitate, discreditarea (denigrarea) concurenților şi deturnarea clientelei. Acestea acțiuni sunt calificate ca acte de concurență neloială încă de la semnarea Convenției de la Paris (1883), în redacția din 1900, respectiv se regăsesc în legislațiile naționale tuturor semnatarelor ale acesteia.

\section{Discreditarea concurentului în domeniul on-line}

Conform DEX, a discredita (Academia Română, Institutul de Lingvistică “Iorgu Iordan”, 2009) semnifică a face să-şi piardă sau a-şi pierde creditul, consideraţia, încrederea altora, a se compromite şi provine de la francezul discréditer. În literatura de specialitate "discreditarea” mai este numită şi „denigrare”. Însăşi legea ne prezintă noțiunea discreditării ca fiind defăimare, punerea în pericol a reputației sau credibilității. Defăimarea (Academia Română, Institutul de Lingvistică "Iorgu Iordan”, 2009) semnifică acțiunea de a vorbi pe cineva de rău pe nedrept, a spune lucruri neadevărate despre cineva. Reputația (Academia Română, Institutul de Lingvistică "Iorgu Iordan", 2009) este o părere, o apreciere publică, favorabilă sau defavorabilă, despre cineva sau ceva; felul în care cineva este cunoscut sau apreciat, renume, faimă, celebritate.

Legea nr. 64 din 23.04.2010 cu privire la libertatea de exprimare ${ }^{1}$ operează cu noțiunea de „defăimare”, definind-o ca fiind acțiunea de răspândire a informațiilor false care lezează onoarea, demnitatea şi/sau reputația profesională a persoanei.

\footnotetext{
${ }^{1}$ Monitorul Oficial nr. 117-118 din 09.07.2010.
} 
În viziunea doctrinarului român Octavian Căpățină, prin denigrare, ca act de concurență neloială, înțelegem actul ce constă în comunicarea sau răspândirea unor afirmații depreciative sau comparative făcute de o persoană interesată (agentul economic agresiv) în detrimentul unui competitor de pe piaţă, în scopul de a-i ştirbi reputația sau de a-i discredita întreprinderea ori produsele (Căpățină, 1996). OMPI defineşte discreditarea (denigrarea) drept răspândire a orice informație falsă, referitoare la un concurent care îi poate afecta fondul comercial. Aşa ca înşelăciunea, discreditarea încearcă să atragă clienții cu informații incorecte. Spre deosebire de înşelăciune, totuşi, acest lucru nu se face prin declaraţii false sau înşelătoare despre produsul propriu, ci mai degrabă prin difuzarea informațiilor neadevărate despre concurent, bunurile sau serviciile acestuia. Prin urmare, discreditarea implică întotdeauna un atac direct asupra unei întreprinderi sau unei anumite categorii de întreprinderi, însă consecințele acestuia depăşesc acest obiectiv; dat fiind că informaţiile despre concurent sau produsele lui sunt incorecte, consumatorul este susceptibil să sufere şi el (WIPO, 2004). În opinia unor autori, denigrarea (discreditarea) constă în afirmarea sau răspândirea sub orice formă, în scop de concurență, de date privitoare la o altă întreprindere, de natură a-i prejudicia reputația (Eminescu, 1995). Prin denigrare se mai înțelege săvârşirea unui act, îndreptat împotriva bunului renume al unui concurent, al întreprinderii, produselor şi/sau serviciilor sale (Copețchi \& Martin, 2015). Legislaţia franceză precizează că denigrarea reprezintă totalitatea acțiunilor care au ca scop deprecierea sau discreditarea Industriei, comerțului sau produsele unui concurent; denigrarea poate rezulta şi dintr-o simplă comparare sau chiar dintr-o simplă aluzie (Cotuțuiu \& Sabău, 2008, p. 81).

În opinia noastră, prin denigrare înțelegem acea acțiune sau act de concurență neloială de răspândire a informațiilor neautentice, care pun în pericol activitatea concurentului.

În Republica Moldova, discreditarea poate avea loc prin două modalități (art. 15 din Legea concurenței nr. 183/2012):

1. Indirectă - răspândirea de către o întreprindere a informațiilor false despre activitatea şi/sau produsele sale;

2. Directă - răspândirea de către o întreprindere a unor afirmații false despre activitatea şi/sau produsele unui concurent.

Ambele modalităţi presupun un comportament activ şi intenţionat de răspândire a informațiilor neautentice de către autorul acestui act. Răspândirea constă dintr-un ansamblu de acțiuni ce au drept rezultat aducerea la cunoştinţa publicului sau a unor persoane concrete a anumitor informațiii. Această acțiune poate fi realizată prin intermediul oricăror forme 
de publicitate, metode, purtători şi mijloace de comunicare audiovizuală şi de altă natură, utilizate pentru transmiterea informației.

Drept exemplu ilustrativ ale discreditării indirecte poate servi acțiunile de concurență neloiale, calificate prin Decizia Plenului Consiliului Concurenței nr. 49 din 22.10.2016. Astfel, s-a constatat faptul că 10 întreprinderi au răspândit informații false (cele mai dese ori prin intermediul paginilor web, rețelelor de socializare sau platformei www.booking.com) despre serviciile pe care le prestează şi anume - au atribuit un număr mai mare de stele unităţilor lor de cazare şi/sau au autodenumit structurile în hotel. Acest lucru le avantajau în raport cu alţi concurenți şi au indus în eroare pe consumatori, în rezultat deturnând clientela rivalilor săi. Totodată, prin acestea acțiuni au fost discreditaţi concurenții. Şi anume - atribuind în mod arbitrar structurilor lor un anumit tipaj (hotel, botel, motel, vilă etc.) şi/sau număr de stele, se denaturează percepția dintre aceste nivele de clasificare. În consecință, prin efectul comparației realizată de consumatori, poate fi pusă la dubiu calitatea serviciilor oferite de hotelele, spre exemplu de, „4 stele” autentice şi nu doar a acestora. Orice denaturare a acestei asocieri dăunează imaginii integrale a pieței prestării serviciilor de cazare, astfel încât lipsa certitudinii în autenticitatea informațiilor răspândite despre structurile de cazare poate să ridice dubii referitor la nivelul de clasificare şi, respectiv, calitatea serviciilor prestate de către acestea. În consecință, poate fi pusă în pericol reputaţia şi credibilitatea tuturor participanților acestei piețe în fața consumatorilor, cât locali, atât şi oaspeţilor din alte state, ceea ce poate leza imaginea RM pe plan turistic internațional.

În practică autorității de concurență a Republicii Moldova au fost investigate câteva cazuri de acţiuni de concurență neloială, manifestate prin răspândirea de informații denigrătoare (discreditare directă) despre concurent. Astfel, specificăm cazurile Bilargo, Student Travel şi STM Acord.

În cazul "Bilargo-Prim" S.R.L., soluționat prin intermediul Deciziei CN-07 din 18.02.2016, în spațiul internet a fost plasat un material video prin intermediul căruia se realizează o comparație cu produsele întreprinderii concurente în ceea ce priveşte conținutul spumei poliuretanice comercializate de către „Comarsini-Grup” S.R.L. Caracterul fals al informațiilor nu a putut fi probat, considerent din care investigația a încetat şi acțiunile întreprinderii reclamate au fost calificate drept publicitate neonestă.

În ceea ce priveşte cazurile "Student Travel" S.R.L. şi "STM Acord" S.R.L., soluționate prin intermediul Deciziilor nr. 24/17-77 din 25.10.2018 şi nr. 25/17-78 din aceeaşi dată, respectiv, informația a fost răspândită de către reclamatul "Center for American Exchange Programs" S.R.L. cu referire la 
activitatea primelor. Răspândirea informațiilor a avut loc prin intermediul paginii web administrate de către partea reclamată. În cazul "Student Travel" S.R.L., investigația a fost încetată pe motiv că nu au fost identificate probe suficiente în sensul determinării caracterului fals al afirmațiilor "Center for American Exchange Programs" S.R.L., iar în cazul "STM Acord" S.R.L., investigaţia a fost încetată pe motiv că ultima şi-a retras plângerea.

\section{Deturnarea clientelei în internet}

La art. 18 din Legea concurenței nr. 183/2012 este prevăzută actul de concurență neloială „Deturnarea clientelei concurentului”. In acest sens se menționează faptul că este interzisă deturnarea clientelei concurentului, realizată de întreprinderi prin inducerea în eroare a consumatorului cu privire la natura, modul şi locul de fabricare, la caracteristicile principale, inclusiv utilizarea, cantitatea produselor, prețul sau modul de calculare a prețului produsului. Acest act de concurență neloială este prevăzut şi în legislația României şi a Federației Ruse, însă cu unele deosebiri.

\section{România}

În conformitate cu prevederile art. 2 alin. (2) lit. b) al Legii privind combaterea concurenței neloiale din România nr. 11 din 29.01.1991, sunt interzise practicile de concurență neloială, după cum urmează: b) deturnarea clientelei unei întreprinderi de către un fost sau actual salariat/reprezentant al său ori de către orice altă persoană prin folosirea unor secrete comerciale, pentru care respectiva întreprindere a luat măsuri rezonabile de asigurare a protecției acestora şi a căror divulgare poate dăuna intereselor acelei întreprinderi. Astfel, observăm că reglementările din Republica Moldova şi România cu privire la deturnarea clientelei sunt puțin diferite. Un prim indicator care le deosebeşte este subiectul care deturnează clientela: întreprinderile, de regulă concurente, în Moldova, şi angajatul sau orice altă persoană, în România. Spre exemplu, prin Decizia nr. 1430/2003 din 06.03.2003, Curtea Supremă de Justiție din România a constatat deturnarea clientelei în următoarea situație: pârâții, persoane fizice, au fost angajaţii societății reclamante, având ca atribuții distribuirea produselor abrazive Hermes, dar, începând cu luna septembrie 1999, şi-au dat demisia şi au continuat, prin intermediul societății pârâte, comercializarea aceloraşi produse către aceiaşi beneficiari, exploatând relaţiile comerciale ale societăţii la care au fost angajați, prin deturnarea clientelei, scăzând cifra de afaceri în comparație cu cea a pârâților, care a crescut simțitor. În Republica Moldova, ar fi posibilă o asemenea calificare doar dacă este prezent factorul inducerii 
în eroare a consumatorului în privința produsului, eroarea generată de către autorul deturnării.

Analizând prevederile legislative din România invocate mai sus, observăm că un element calificativ al deturnării clientelei este folosirea secretului comercial, iar în cazul lipsei acestui element nu suntem în prezența deturnării clientelei. În Republica Moldova, deturnarea clientelei nu presupune utilizarea secretului comercial, deoarece în acest sens este prevăzută o altă acțiune de concurență neloială - obținerea şi/sau folosirea ilegală a secretului comercial al concurentului. În lumina acestor concretizări, considerăm prevederile autohtone mai eficiente faţă de cele din România, anume pe acest segment, deoarece în Republica Moldova se urmăreşte şi protecția consumatorilor faţă de informațiile eronate oferite de întreprinderi. In România, deturnarea clientelei presupune şi situația că, clienții conştient, benevol migrează de la întreprindere la alta având ca punct de raportare un anumit salariat, care datorită calităților personale şi profesionale poate menține un cerc clientelar în jurul său. În Republica Moldova, însă, o asemenea migrare nu constituie un element calificativ al concurenței neloiale, deoarece consumatorul este liber să decidă cu ce întreprindere stabileşte raporturi. Doar migrarea clientelei de la un concurent la altul, ca urmare inducerii în eroare, poate constitui o deturnare de clientelă.

\section{Rusia}

Art. 14 alin. (1) pct. 2) din Legea privind protecția concurenței din Federația Rusă nr. 135-F3 din 26.07.2006 de asemenea, prevede acțiunea de deturnare în următoarea formulă: inducerea în eroare în ceea ce priveşte natura, modul şi locul de producție, proprietățile de consum, calitatea şi cantitatea produselor sau în ceea ce priveşte producătorii produselor. Acest ansamblu de elemente calificative are o arie mai largă de aplicare şi, implicit, mai multe fapte ale subiecților pot fi calificate drept deturnare, spre deosebire de reglementările din Moldova şi România, deoarece în Federația Rusă nu este stabilită necesitatea existenței sau posibilei surveniri a efectului deturnării clientelei, care presupune migrarea clientelei de la un concurent la altul.

Gravitatea acțiunii de deturnare a clientelei decurge din faptul că este afectată cea căreia i se adresează de fapt concurentul: clientela. Utilizarea modalităţilor de deturnare a consumatorilor satisfăcuți demonstrează, de fapt, incapacitatea unui subiect economic de a se afirma pe piaţa unor produse/servicii, de a atrage un anumit segment de clientelă, de a putea beneficia de încredere şi fidelitate din partea clientului. Cele evidențiate a priori urmează a fi dobândite de un concurent cu bună-credinţă nu peste 
noapte, ci cu depunerea eforturilor de-a lungul unei perioade îndelungate de timp. Dobândirea legală a clientelei şi a încrederii acesteia poate fi realizată doar prin străduinţa prodigioasă a operatorului economic manifestată prin: calitatea şi caracteristicile produsului/serviciului, prețul, modalitatea prin care e adusă la cunoştința publicului, publicitate, ambalaj, eficiență etc.

Legea concurenței nu defineşte noțiunea deturnării clientelei, prezentând doar modalitățile prin care se poate realiza deturnarea clientelei. Noțiunea de clientelă înglobează în sensul său şi noţiunea de consumator. Potrivit art. 4 din Legea concurenței, consumator este acel utilizator, direct sau indirect, de produse, inclusiv producător care utilizează produse pentru prelucrare, comerciant cu ridicata, comerciant cu amănuntul sau consumator final. Totodată, în conformitate cu art. 1 din Legea nr. 105 din 13.03.2003 privind protecția consumatorilor, consumatorul este orice persoană fizică ce intenționează să comande sau să procure ori care comandă, procură sau foloseşte produse, servicii pentru necesități nelegate de activitatea de întreprinzător sau profesională. Evidențiind aceste criterii, observăm că Legea concurenței prevede un cerc mai larg de subiecte care pot avea calitatea de consumator, acestea fiind atât persoane fizice, cât şi juridice. Legea privind protecția consumatorilor, însă, restrânge cercul consumatorilor doar la persoanele fizice. În aces caz, considerăm necesară a fi reținută definiția mai cuprinzătoare oferită de Legea concurenței, deoarece este specifică dreptului concurenței.

Un caz de deturnare a clientelei prin intermediul rețelelor de socializare, precum şi prin intermediul platformelor pentru rezervările online a fost investigat recent de către Autoritatea de Concurență şi Piață din Marea Britanie. Astfel, autoritatea menţionată a impus măsuri provizorii celor 6 platforme care activează în domeniul rezervărilor on-line. Măsurile respective constau în înlăturarea tuturor practicilor înşelătoare practicate de către platformele respective: informații eronate cu privire la numărul de locuri rămase disponibile în cadrul structurilor de cazare, cu privire la prețul de rezervare şi cu privire la calitatea în plan comparativ a anumitor structuri in raport cu altele.

\section{Crearea confuziei în domeniul on-line}

Potrivit Dicționarului explicativ al limbii române, confuzia (din latinescul confusio) derivă de la verbul a confunda. A confunda se explică drept acțiunea de a lua o persoană drept alta sau un lucru drept altul, a asemăna, a asemui, a forma un singur tot, a se contopi. 
Reglementarea confuziei în lege este foarte riguroasă. Astfel că, se interzic orice fapte, realizate prin orişice mijloace, de natură să creeze confuzie şi poate aduce atingere intereselor legitime ale titularului. Este evidentă intenția legiuitorului de a crea o normă cu aplicabilitate pentru prezent şi viitor, or acţiunile şi mijloacele prin care poate fi creată confuzia evoluează rapid, de la simple texte publicitare până la setarea anumitor programe on-line. Prin prisma normei citate, rezultă că confuzia este o componență de acțiune de concurență neloială formală. Aceasta este prezentă din momentul punerii în practică a acțiunilor de natură să creeze confuzia. Pentru a califica realizarea unei confuzii nu este necesară producerea anumitor prejudicii concrete, este de ajuns faptul că acțiunea înfăptuită să presupună un efect de confuzie şi poate aduce atingere intereselor legitime ale titularilor proprietăţii intelectuale. Consecințele păguboase ale confuziei vor fi luate în considerare la stabilirea amenzii (Gorincioi \& Creciun, 2016, p. 13).

În sensul Legii concurenței 183/2012 este sancționabilă fapta, care este de natură să creeze o confuzie. În această ordine de idei, pentru calificare este necesară doar argumentarea justificată şi constatarea că acțiunile concurentului sunt de aşa natură, întrucât ar putea crea confuzie. Această constatare se realizează de către Plenul Consiliului Concurenței. Faptul, dacă confuzia s-a produs sau nu, poate fi constatat doar prin chestionarea consumatorilor de produse care se presunpune că ar fi confundate. Probarea realizării confuziei poate fi efectuată atât de către Consiliul Concurenței, cât şi de către autorul plângerii. Această constatare, însă, va avea impact nu atât asupra calificării, cât asupra precizării cuantumului sancțiunii.

În privința calificării conceptului de ,fapte de natură să creez̧e confurie" şi a acelor circumstanțe care sunt de natură să creeze confuzie, în practică se depistează abordări incongruiente.

Potrivit Deciziei Plenului Consiliului Concurenței nr. CN-16 din 14.04.2016, s-a calificat încălcarea art. 19 alin. (1) lit. a) al Legii concurenței de către întreprinderea „Online Broker de Asigurare” S.R.L. manifestată prin folosirea ilegală, integrală şi parţială, a mărcii comerciale „rapidasig”, care-i aparţine întreprinderii „MGP Broker” S.R.L., în publicitatea, difuzată prin intermediului programului on-line de publicitate „AdWords” şi al motorului de căutare Google. „Folosirea mărcii „rapidasig” de către intreprinderea „Online Broker de Asigurare” S.R.L. este ilegală, integrală și partială şi este de natură să creeze o confurie cu marca "rapidasig”, folosită în mod legal de către titularul de drept, intreprinderea „MGP Broker" S.R.L."

Un alt caz de acțiuni de concurență neloială în domeniul on-line a fost constatat prin Decizia Plenului Consiliului Concurenței nr. CN-57 din 
03.09.2015. Întreprinderea „Eurolumina” SRL, susţinea că la data de 04.07.2014 a constatat că întreprinderea „Volta” SRL a înregistrat numele de domen www.1000kv.md, care este asemănător cu marca „1000kw centru comercial”, denumirea centrului comercial „1000kw” şi denumirea numelui de domen www.1000kw.md, pe care le deține. Urmare a investigației, autoritatea de concurență a stabilit că ,întreprinderea „VOLTA” S.R.L., prin crearea paginii web cu numele de domen www.1000kv.md a folosit parțial marca „1000kw centru comercial”, prin care se creează confuzie cu marca innregistrată şi utilizată în mod legal de către întreprinderea „EUROLUMINA” S.R.L.”. Totodată, şi „Eurolumina” SRL avea înregistrat un nume de domen asemănător $\mathrm{cu}$ marca proprie, şi anume: www.1000kw.md. În consecință, a fost constatată încălcarea prevederilor art. 19 alin. (1) lit. a) din Legea concurenței de către întreprinderea „Volta” SRL prin folosirea ilegală parţială a mărcii „1000 KW centru comercial”, ce aparține întreprinderii „Eurolumina” SRL şi a aplicat o amendă în mărime de 905252,91 lei.

Decizia a fost atacată la Curtea de Apel Chişinău, care a respins ca neîntemeiată acțiunea civilă. Instanța a reținut că prin cererea de chemare în judecată reclamantul invocă argumente contradictorii, deoarece, pe de o parte - neagă comiterea faptei imputate acestuia, invocând ilegalitatea în acest sens a deciziei contestate, iar pe de altă parte - susține că încălcarea admisă este minoră şi nu urma a fi sancționată, inclusiv ca urmare a nivelului redus de vizitare a paginii web www.1000kv.md şi lipsa unor probe referitoare la prejudiciul cauzat petiționarului - situație ce denotă că însăşi reclamantul admite comiterea încălcării Legii Concurenții care îi este imputată şi pentru care i-a fost aplicată sancțiunea. Decizia Curții de Apel Chişinău a rămas irevocabilă prin neatacare. Acest fapt ne conduce către ideea conştientizării de către întreprinzător a comportamentului neloial.

Un alt caz relevant în acest sens este cazul "Daybegin" S.R.L. Astfel, a fost constatată încălcarea de către ultima a prevederilor art. 19 alin. (1) lit. a) din Legea concurenței prin utilizarea parțială a numelui de domen "www.babyboom.md", marcă ce aparține întreprinderii "Totul pentru copii" S.R.L., utilizată inclusiv ca nume de domen sub forma "www.babyboom.md"

Astfel, în cazurile sus menționate („Volta” S.A. țo „Daybegin” S.R.L.) a avut loc aşa zisul fenomen de tipe-squatting (din limba engleză «squatting» - capturarea ilegală a spatiilor vacante sau a teritoriilor). În numele de domeniu sau numele unei mărci comerciale, deseori notorie, se preconizează admiterea unei greşeli de scriere. 
Din punct de vedere al fenomenului concurenței neloiale, unul din cele mai mari pericole reprezentă cyber-squatting (capturarea numelor de domenii). Esența acestui tip de squatting constă în înregistrarea unor semne, sintagme etc., care la moment nu sunt înregistrate ca mărci comerciale sau nume de domenii într-o țară, dar deja sunt obiecte al proprietăţii intelectuale în altă țară. Scopul acestor acțiuni este vânzarea ulterioară a acestor obiecte de proprietate intelectuală deja înregistrate, în calitate de mărci sau nume de domenii, persoanelor interesate. De regulă persoane interesate sunt titularii de mărci sau domenii bine cunoscute în alte state sau acele persoane care categoric doresc să achiziționeze o marcă sau domeniu deja înregistrate pentru afacerea lor.

În 2016 titularii de mărci au depus la Organizația Mondială de Proprietate Intelectuală (OMPI) un număr record de 3,036 de cereri de soluționare a disputelor cu privire la numele de domenii înregistrate cu presupusa rea-credință, prin procedura Politicii uniforme de soluţionare a litigiilor în domeniul numelor de domen (UDRP - Uniform Domain Name Dispute Resolution Policy), ceea ce reprezintă o creştere de $10 \%$ faţă de 2015. Acest fenomen, cunoscut sub denumirea de cybersquatting, se datorează apariției a peste 1200 de domenii generice de nivel superior (gTLD) operaționale în prezent (Agentia de Stat pentru Proprietatea Intelectuala, 2017).

În procesul investigării cazurilor de încălcare a legislației concurențiale autoritatea de concurență se confruntă cu un şir de probleme, cum ar fi: imposibilitatea obținerii informațiilor de la motoarele de căutare externe (cum ar fi, Google), deseori - imposibilitatea identificării persoanei, care deține pagina web chiar şi pe domenul .md În prezent, procedura de achiziționare a domeniilor în Republica Moldova se poate realiza on-line, pe site-ul Moldata, fără a fi necesară prezentarea vreunei informații cu privire la proprietar, fie că este vorba despre o persoană fizică sau despre o persoană juridică.

\section{Concluzii}

Principalul scop al actelor de concurență neloială este obținerea clientelei, care în cea mai mare măsură este acaparată prin intermediul campaniilor publicitare. Prețul scăzut per contact şi diversitatea conceptelor creative disponibile au ca rezultat popularizarea pieții publicitare on-line.

Din ce în ce mai multe întreprinderi aleg mediul online, în defavoarea pieței TV şi out of home. Astfel, piaţa publicităţii în domeniul on-line creşte în mod continuu, atât în termeni de accesare a pieții, cât şi din perspectiva sumelor financiare. 
O problemă importantă pe piața publicității pe internet din Moldova este reprezentată de absența verificării conținutului distribuit prin intermediul site-urilor web locale, ceea ce creează premisele necesare pentru apariția unor probleme concurențiale pe piața specifică.

Adoptarea imediată a Legii publicității din Republica Moldova în domeniul publicității pe internet este necesară pentru protejarea şi stimularea concurenței pe teritoriul țării.

Per a contrario, lipsa unei asemenea reglementări ar contribui la creşterea numerică a a cazurilor de concurență neloială identificate în spaţiul internet.

\section{References}

Academia Română, Institutul de Lingvistică „Iorgu Iordan” (2009). Dicționarul explicativ al limbii române. Bucuresti: Editura Univers Enciclopedic Gold.

Agentia de Stat pentru Proprietatea Intelectuala (2017). Record de cazuri de cybersquatting inregistrate la OMPI in anul 2016. Retrieved from http://agepi.gov.md/ro/news/record-de-cazuri-de-cybersquatting$\%$ C3\%AEnregistrate-la-ompi-\%C3\%AEn-anul-2016

Căpățînă, O. (1996). Dreptul concurențtei comerciale. Concurența neloială pe piața internă și internatională. București: Editura Lumina Lex.

Consiliul Concurentei (2016). Plenul Consiliului Concurentei. Decizie. Retrieved from https://competition.md/public/files/Decizia-CN-49-din22102016neconfid7331f.pdf

Copețchi, S., \& Martin, D. (2015). Discreditarea concurentului - formă de exprimare a infracțiunii de concurență neloială. Revista Intellectus, 4, pp. 1520.

Cotuţuiu, A., \& Sabău, G. (2008). Drept român şi comunitar al concurenţei. Bucureşti: Editura Ch. Beck.

Decizia Plenului Consiliului Concurenței nr. CN-16 din 14.04.2016. Retrieved from https://competition.md/public/ files/Decizia-Plenului-ConsiliuluiConcurentei-nr-CN-16-din-1404201651e75.pdf (accessed at 02.12.2017).

Eminescu, Y. (1995). Concurența neleală: drept român şi comparat. Bucureşti: Editura Lumina Lex, p. 75.

Gorincioi, C., \& Creciun, I. (2016). Combaterea acțiunilor de concurență neloială în domeniul proprietății intelectuale. Revista Intellectus, 2, p. 12.

WIPO (2004). WIPO Intellectual Property Handbook. Second edition. Nr. 489 (E), 2004, p. 148. Retrieved from http://www.wipo.int/edocs/pubdocs/en/intproperty/489/wipo_pub_48 9.pdf (accessed at 18.11.2017). 